\title{
Superficial Fungi Skin Infections: The Bane of Dermatoses in Nigeria
}

\section{Olumayowa A Oninla*}

Department of Dermatology and Venereology, Obafemi Awolowo University, Ile-Ife, Osun State, Nigeria

"Corresponding author: Olumayowa A. Oninla, P.O.Box 699, Enuwa, Ile-lfe, Osun State, Nigeria, Tel: +2348058025220; E-mail: mayooni@yahoo.com

Rec Date: May 24, 2014, Acc date: August 27, 2014, Pub date: August 29, 2014

Copyright: (C) 2014 Oninla OA, et al. This is an open-access article distributed under the terms of the Creative Commons Attribution License, which permits unrestricted use, distribution, and reproduction in any medium, provided the original author and source are credited.

\begin{abstract}
Skin conditions affecting the Nigeria populace are mostly infective skin diseases. Various studies across the population done in schools, community or as hospital-based prevalent studies showed that superficial fungi infections made up majority of these infections. These infections constitute the highest number of dermatoses or skin infections treated by dermatologists all over the country. The prevalence of superficial fungi infections has also been observed to remain the same, and in some places, it has increased over decades.

Superficial fungi infections still need to be addressed as a public health problem among the growing populace of Nigeria. The favorable environment of hot and humid climate, poverty, poor sanitary conditions and overcrowding are well known factors that favor these fungi growth. These conditions well abound in Nigeria.
\end{abstract}

Keywords: Fungi infections; Dermatoses; Nigeria

\section{Review}

Fungi are a group of non-photosynthetic micro-organisms which live as saprophytes in the soil and on dead organic matter or as parasites of plants and animals including man [1]. They can be found in the soil, decaying plants, air and water, and as part of the microbial flora of within the body or on the skin of man. There are many species of fungi that causes skin infections in man. These are mainly Dermatophytes (Trichophyton specie, Epidermophyton specie and Microsporum specie), Malassezia furfur and Candida specie. Less commonly Aspergillus specie, Trichothecium roseum, Cladosporium specie, Fusarium specie, Curvularia specie, Penicillium specie, Epidermetaphyton specie, Drechslera specie. and Alternaria specie also cause skin, hair or nail infections [2].

Superficial fungi skin infections are fungal diseases that affect the skin, mucous membrane, nails, and hair. These infections have been reported in various studies in developing countries as the most common dermatoses [3-6] and where they are not; they are usually the second most common skin problems [7] They are also responsible for most of the skin infections among school children [8] In a study of schoolchildren by Amoran et al, $83.7 \%$ of all skin disorders seen in 480 pupils were infective dermatoses with superficial fungal infections (dermatophytoses and pityriasis versicolor) constituting 74.1\% [9].

Ogunbiyi et al reported skin diseases in $35 \%$ of school children with $20.6 \%$ having fungi infections (dermatophytes-15.9\%; pityriasis versicolor-4.7\%) that are mostly tinea capitis (14.5\%) [10]. Odueko et al. in a prevalence survey of 5001 Nigerian children aged $0-12$ years at the Urban Comprehensive Health Centre, Ile-Ife, Nigeria revealed that 492 children (9.8\%) had dermatological conditions with dermatophytic infections in $17.1 \%$ [11].

Fungi skin infection constitutes the majority of infective skin conditions seen by physicians in primary, secondary, and tertiary health care centers, in Nigeria [12-15]. Fungi infections make up the majority of infective dermatoses as well as the most common dermatoses at various dermatology centers in Nigeria. Fungi infections most often reported are the superficial fungi infections which are dermatophytes, pityriasis versicolor and candidiasis. Of these, dermatophytes are usually the most prevalent.

Fungi infections were the most frequently occurring infection in a dermatology clinic at Ibadan by Ogunbiyi et al, in south-west Nigeria affecting $10.9 \%$ (dermatophytes- $4.5 \%$, pityriasis versicolor- $4.5 \%$, and candidiasis-1.9\%) of the patients presenting for care during the study period [16]. A similar study at the same clinic reported 24 years earlier showed that these infections made up $8.9 \%$ (dermatophytes- $6.6 \%$, pityriasis versicolor-1.1\%, and candidiasis-1.2\%) of the skin conditions [17].

A study by Nnoruka, a dermatologist in southern Nigeria demonstrated the preponderance of these infections. They made up $10.1 \%$ of the skin conditions seen in 2871 patients reporting for dermatological care with dermatophytes in $8.3 \%$ (pityriasis versicolor-1.7\%, and candidiasis-0.1\%) [18]. Another study on cutaneous infections in a dermatology clinic by Olasode et al reported these infections as constituting $67 \%$ of all infectious dermatoses seen [19]. Other dermatologists in northern Nigeria reported a higher prevalence. The climate in the northern part is drier and hotter causing increased sweating. The southern part, however, has a hot humid climate with the high humidity predisposing to fungi infections. Yahya found fungi infections in $11.2 \%$ of skin diseases in 5982 patients studied, and these predominantly involved dermatophytes (dermatophytes- $6.0 \%$, pityriasis versicolor- $2.4 \%$, and candidiasis-2.8\%) [20]. An earlier study done 30 years before, reported that dermatophytes were found in $13.8 \%$, and pityriasis versicolor in $2.5 \%$ of 8013 patients [21]. This implies that fungi infections are still highly prevalent in this area. Onayemi et al also found the infections in $21 \%$ of 900 patients (dermatophytes- $10.4 \%$, pityriasis versicolor- $6.7 \%$, and candidiasis-4.9\%) in another northern state in Nigeria [22].

\section{References}

1. Okafor JI. Fungal diseases: a serious threat to human existence in recent times. 
Citation: Oninla OA, et al. (2014) Superficial Fungi Skin Infections: The Bane of Dermatoses in Nigeria. J Med Microb Diagn 3: 152. doi:

Page 2 of 2

2. Gupta S, Gupta BL (2013) Evaluation of the incidences of dermatophillic infection in Rajastahan: Case studies from Rajasthan, India. Int. J. Med. Med. Sci 5:229-232.

3. Bissek AZ, Tabah EN, Kouotou E, (2012) The spectrum of skin diseases in a rural setting in Cameroon (sub-Saharan Africa). BMC Dermatology 12:7.

4. Satimia FT, McBride SR, Leppard B (1998) Prevalence of Skin Disease in Rural Tanzania and Factors Influencing the Choice of Health Care, Modern or Traditional. Arch Dermatol 134:1363-1366.

5. Doe PT, Asiedu A, Acheampong JW, (2001) Skin diseases in Ghana and the UK. Int J Dermatol 40: 323-326.

6. Souissi A, Zeglaoui F, Zouari B, (2007) A study of skin diseases in Tunis. An analysis of 28,244 dermatological outpatient cases. Acta Dermatoven APA 16:111-116.

7. Figueroa JI, Fuller LC, Abraha A, (1998) Dermatology in southwestern Ethiopia: rationale for a communityapproach. Int J Dermatol 37:752-758.

8. Oyedeji OA, Onayemi O, Oyedeji GA, Oyelami O, Aladekomo TA, Owa JA, et al. (2014) Prevalence and pattern of skin infections and infestations among primary school pupils in Ijeshaland.

9. Amoran OE, Runsewe-Abiodun OO, Mautin AO, Amoran IO (2010) Determinants of dermatological disorders among school children in Sagamu, Nigeria. Educ Res 2:1743-1748.

10. Ogunbiyi OA, Owoaje E, Ndahi A (2005) Prevalence of Skin Disorders in School Children in Ibadan, Nigeria. Pediatr Dermatol 22: 6-10.

11. Odueko OM, Onayemi O, Oyedeji GA (2001) A prevalence survey of skin diseases in Nigerian children. Niger J Med10: 64-67.
12. WHO/CAH (2005) Epidemiology and Management of Common Skin Diseases in Children in Developing Countries.

13. Olasode OA, Henshaw EB, Akpan NA, Agbulu RE (1966) The Pattern of Dermatoses in a Skin Clinic in Calabar,Nigeria: A Baseline Study. Clinical Medicine Insights: Dermatology

14. Shrank AB, Harman RRM. The incidence of skin diseases in a Nigerian teaching hospital dermatology clinic. Br J Dermatol 78: 235.

15. Emodi IJ, Ikefuna AN, DuruUA (2010) Skin diseases among children attending the children outpatient clinic at the University of Nigeria teaching hospital Enugu, Nigeria. Afr Health Sci 10: 362-366.

16. Ogunbiyi AO, Daramola OOM, Alese OO (2004) Prevalence of skin diseases in Ibadan, Nigeria. Int J Dermatol 43: 31-36.

17. Alabi GO (1980) Trends in the pattern of skin diseases in Nigeria. Nig Med J 10:163-168.

18. Nnoruka EN (2005) Skin diseases in south-east Nigeria: a current perspective. Int J Dermatol. 44: 29-33.

19. Olasode OA, Otu AA, Henshaw EB, Akpan NA (2009) Cutaneous Infections in Patients Presenting in a Skin Clinic in the Tropics. International Journal of Tropical Medicine Year 4: 119-122.

20. Yahya $\mathrm{H}$ (2007) Change in pattern of skin disease in Kaduna, northcentral Nigeria. Int J Dermatol 46: 936-943.

21. Fekete E (1978) The pattern of diseases of the skin in the Nigerian Guinea savanna. Int J Dermatol 17: 331-338.

22. Onayemi O, Isezuo SA, Njoku CH (2005) Prevalence of different skin conditions in an outpatients' setting in north-western Nigeria. Int J Dermatol 44: 7-11. 